\title{
LINE AND COLOUR CREATION-ART THERAPY FOR PSYCHOTIC PATIENTS IN THE UILS (UNIT INFORMASI LAYANAN SOSIAL, UNIT OF SOCIAL SERVICE INFORMATION) MERUYA
}

\author{
Nina Maftukha, Ariani Wardhani, Pandan Jati \\ Universitas Mercu Buana Jakarta, Indonesia
}

\begin{abstract}
Art Therapy is one of the solutions that might be applied in the movement of pursuing mental health awareness within the Indonesian society. The methods in Art Therapy combine the approaches from art, design and psychology altogether with the other disciplines. One of the examples is the line and colour-creation art therapy. This method might be applied to the patients of mental health disorder such as psychotic. The introduction of line and colour-creation into the art therapy has been inspired by the visual introduction that the infants experience for the very first time. Within the line and colour, there are light intensity, thin and thick line intensity, hand pressure intensity during the sketching activities, emotion intensity that goes after the thick and thin line intensity and also colour intensity altogether with the colour category namely hot, warm and cold. All of these aspects might be benefitted for the recovery process in terms of emotion, self-expression and selfactualization. Then, the line and colour creation-art therapy integrates all kinds of art under comfortable and nonjudgmental situation in order to facilitate the recovery process of the psychotic patients. To use art expressively means to enter the inner space within an individual's heart in order to find the inner feelings and to express these inner feelings in the form of visual art, movement, voice, writings and drama. This process encourages the freedom, the self-understanding, the insight and also trigger the creativity and the transpersonal awareness so that the recovery period might be increased by expressing the feelings onto a sheet of paper. In this case, the position of art as an existential phenomenon becomes a bridge that unites rite, imagination and fantasy in such a way that other activities might be unable to perform since the objective of art is to represent the significance of an individual's inner feeling instead of outer appearance. In other words, art might be considered as a symbolic form of human's feelings. Departing from this elaboration, the researcher would like to initiate the implementation of a Community Service Program in UILS (Unit Informasi Layanan Sosial, Unit of Social Service Information) Meruya Selatan under the authority of Bina Laras Harapan Sentosa 1 Social Homes Cengkareng. The results of the Community Service Program are expected to increase the rate of psychotic patients' recovery process by means of expression painting therapy for overcoming the mental health disorders.
\end{abstract}

Keywords : Art Therapy, Creativity, Colour Creation, Psychotic

\section{INTRODUCTION}

The UILS (Unit Informasi Layanan Sosial, Unit of Social Service Information) under the authority of the Social Department of the Province of Jakarta Special Capitol serves as an information channel that focuses on the handling of ODGJ (Orang Dengan Gangguan Jiwa, People with Mental Disorders) and ODMK (Orang Dengan Masalah Kejiwaan, People with Mental Problems). One of the objectives that UILS, located in Meruya Selatan Street No. 33 Kembangan West Jakata, has been pursuing is to change the society perspective by eliminating the negative stigma toward the people with mental health disorders, specifically the psychotic patients, through a number of activities that have been implemented. The most important reason behind such pursuance is to improve the life quality of and to protect the psychotic patients from the unexpected harms. As having been explained, the pursuance of the objective is in the form of therapy or other activities such as culinary training, music introduction, sewing, creating dolls and alike. Specific to these activities, up to date the psychotic patients in UILS Meruya has been mentored in their painting activities so that their paintings describe the intuition and the expression of each psychotic patients. Despite the excellent activities, UILS Meruya has difficulties in gathering the family members of the patients during the consultation session between the norroholomint and the norrohnotin notionts 


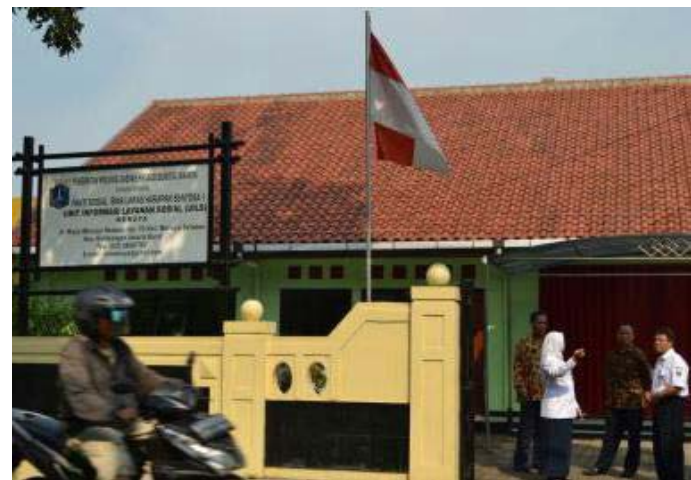

Figure 1. Unit of Social Service Information Meruya Selatan

Source : Maftukha, 2018

\section{THEORETICAL REVIEW}

Referring to the item of Situation Analysis, the difficulty that UILS Meruya has been experiencing is related to gathering the family members during the consultation session between the psychologist and the psychotic patients. Therefore, the researcher has an initiative to hold an expression painting class in order to assist the family members to read and identify the psychological condition of the psychotic patients or to read and identify the mental problems by means of expressing painting analysis from each psychotic patient. The reason is that expressing painting activities are one of the art therapy media that might be applied to the mental health disorder patients or even the psychotic patients.

In relation to the above description, Art Therapy has been considered as one of the effective solution that might be applied into the movement of pursuing mental health awareness within the Indonesian society. The methods in Art Therapy combine the approaches from Art, Design, Psychology and other relevant disciplines. Then, within the conduct of the Community Service Program, the Art Therapy will be implemented as the therapy medium for the recovery process of the other mental disorders that might range from stress to depression, paranoid, schizofrenia and even more. According to Wallas (1926), the Art Therapy is divided into four stages of creation process namely:

1. Preparation

In this stage, the researcher and the team of Community Service will explore the problem.

2. Incubation

In this stage, the researcher and the team of Community Service will gather the relevant data, information and experience from the subconscious or the pre-conscious aspects of the respondents. Then, the data, the information and the experience that have been gathered will be formulated into a problem solution.

3. Illumination

In this stage, the researcher and the team of Community Service will clarify the ideas and the solutions for the given problem.

4. Verification

In this stage, the researcher and the team will test and improve the ideas. In addition, within this stage the mind consciously and logically takes over the process and performs its own activities based on the input from the previous unconscious process.

The support toward theory of Wallas appears from the results of psychoanalytic works by Kris (1952) and Kubie (1958). According to Kris, a creative performance involves a phase of inspiration followed by an elaboration period. Each stage in the creative performance has different mental activities and awareness level.

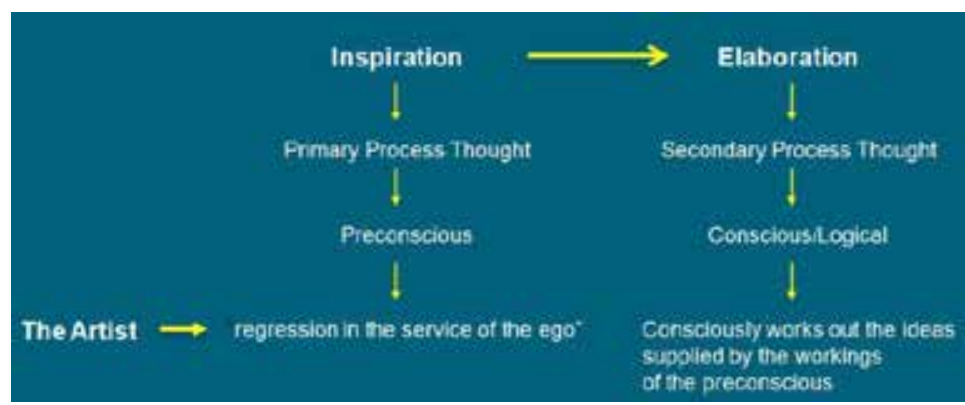

Figure 3. Phase of inspiration

Source: Damajanti, 2010 
The phase of inspiration is led by the primary process thought. Freud states that primary process thought refers to a thinking type that is irrational, irregular and tolerant toward contradiction or illogical aspects. Still according to Freud, the primary process thought is located in the unconscious mind. However, according to the revision toward the psychoanalytic theory by Kris, the primary process thought is located in the pre-concscious mind or one level closer to the surface (conscious mind) according to the theory of subconscious mind by Freud. According to Kris, when an individual is in the phase of inspiration, he or she will draw himself or herself back into the pre-conscious mind temporarily or to the level of primary process thought. This situation is related to the stage of incubation that has been described by Wallas. The withdrawal that has been associated to the creative thinking manner is depicted as the regression in the service of ego as a differentation from the other types of regression within the cases of mental disorder. The stage of withdrawal is followed by the stage of work elaboration through the logical and aware secondary process thought, a stage that has been related o the verification according to the theory of Wallas. In this stage, all individuals, especially artists, work consciously and pour out the ideas that they have generated from the pre-conscious mind.

In order to test the statement that creativity is a multi-phase process that involves the stage of preconscious incubation, Patrick $(1935,1937)$ has requested the poets, the painters and the scientists within their performance under a creative problem. Their description about the mental process that has been experienced provides evidence for the four stages of creation process and supports the multi-phase view of the creativity. However, as having been understood by Patrick alone, the study has not led to a firm conclusion that the period known as incubation truly involves the unconscious process.

Still in relation to the creation process, Arnheim provides a new perspective on the case by arguing that in displaying their creativity the artists strive to solve their problems by exerting the overall awareness and intellectual capacity that they possess. This kind of problem solving activity involves visual thinking and the results that have been attained are directed toward the strong consideration of form and willingness in order to express a peculiar meaning. Every selection of shape, colour and line becomes a symbol that might interpret the desire of the artists into the visual form. Based on the results of the previous studies about the creation process in artwork, the researcher would like to state that the painting therapy will be able to uncover the level of intelligence, emotion, concentration and thinking capacity. As a result, people with mental disoders, specifically the psychotic patients, will be invited to identify their problems by means of self-exploration and to perform their creativity by means of brush and paint-game. Through these activities, it is expected that these people will find enthusiasm, inspiration, new dreams and appropriate solutions for starting the whole new page in their life.

\section{METHOD}

The strategic object within the conduct of the Community Service Program was the people with mental disorders, or specifically the people with psychotic disorders, in the UILS (Unit Informasi Layanan Sosial, Unit of Social Service Information) South Meruya. Then, the methods that had been implemented in the program were as follows:

\section{Lecture}

This method was implemented by providing directions toward thealternatives of media, materials, tools (brushes), markers and colours to the pyschotic patients.

2. Question and Answer

This method was implemented in order to provide the opportunities for the partcipants to gain deeper understanding toward the activities.

3. Direct Practice

This method was intended to provide direct opportunity for the participants to draw their line and colour.

Then, the Community Service Program was conducted through the following stages:

1. Preparation

In the first stage, the team of Community Service handled the permission papers and directly approached the caretakers and the psychotic patients in the UILS (Unit Informasi Layanan Sosial, Unit of Social Service Information) located in Meruya Selatan Highway, Kembangan District, Meruya Selatan Village, West Jakarta.

2. Implementation

In this stage, the team of Community Service altogether with the researcher implemented the Line and Colour Creation-Art Therapy. Within the implementation of the art therapy, it was expected that the participants would be very active in attending the training program. The participants would be divided into several groups and each group would be mentored by the team of Community Service during the training process. At the end of the implementation, the results of expressive painting activities would be displayed. 


\section{ACTIVITY REPORT}

The reports about the conduct of the training program will be elaborated in the following sections.

\section{Location and Schedule}

The training program was held as part of the initiative by the team of Community Service and the Faculty of Design and Creative Art Mercu Buana University. Then, the training program was entitled "Improving Creativity and Productiveness for the Psychotic Patients in the Unit of Social Service Information (UILS, Unit Informasi Layanan Sosial) Meruya Selatan, West Jakarta." The training program took place from February $14^{\text {th }}$ until February $15^{\text {th }}, 2019$. Then, the number of the training program participants was 9 psychotic patients with different mental disorders. The whole rundown of the training program might be consulted in Table 1 below.

Table 1. Activity Rundown

\begin{tabular}{|c|c|c|}
\hline No & Time & Stage \\
\hline 1 & $08.00-08.30$ & Preparation and Re-Registration for the Participants \\
\hline 2 & $08.30-09.00$ & $\begin{array}{l}\text { Opening: } \\
\text { - Forewords from the caretakers of UILS by Mr. Haryono, S.Sos. } \\
\text { - Forewords from the representative of Social Homes by } \mathrm{Hj} \text {. } \\
\text { Chairani, S.H., M.Kn. } \\
\text { - Forewords from the Chief of Community Service Team by Nina } \\
\text { Maftukha, S.Pd., M.Sn. }\end{array}$ \\
\hline 3 & $09.00-09.30$ & $\begin{array}{l}\text { Session 1: Line and Color Creation-Art Therapy } \\
\text { - Introduction to Art Therapy } \\
\text { - Explanation on the rules and regulations in the Art Therapy } \\
\text { activities } \\
\text { - Healing and sport exercise }\end{array}$ \\
\hline 4 & $09.30-11.00$ & $\begin{array}{l}\text { Session 2: Core Activities } \\
\text { - Drawing } 10 \text { lines from the left to the right by using the ground } \\
\text { paper with rather abrupt surface and } 12 \text { coloring pencils } \\
\text { - Drawing } 15 \text { lines to the top or to the bottom by using the coffee } \\
\text { paper with } 2 \text { different surfaces (slippery and abrupt) and } 1 \\
\text { coloring marker for each psychotic patient } \\
\text { - Drawing continuous line with irregular directions on the duplex } \\
\text { paper in the form of a circle with } 2 \text { different surfaces (white } \\
\text { slipper surface and grey texturized surface) by using } \\
\text { independently selected brush and paint } \\
\text { - Drawing expressive line with irregular directions on the duplex } \\
\text { paper in the form of a circle with } 2 \text { different surfaces (white } \\
\text { slipper surface and grey texturized surface) by using } \\
\text { independently selected brush and paint } \\
\text { - Drawing expressive line with irregular directions on the linen } \\
\text { paper in the form of a circle by using independently selected } \\
\text { brush and paint } \\
\text { Drawing expressive line with irregular directions on the different } \\
\text { types of paper with different shape, size and color by using } \\
\text { independently selected brush and paint }\end{array}$ \\
\hline 5 & $11.00-11.30$ & $\begin{array}{l}\text { Session 3: Sharing Moment } \\
\text { The psychotic patients share about their best artwork. }\end{array}$ \\
\hline 6 & $11.30-11.40$ & Closing Ceremony and Lunch Time \\
\hline
\end{tabular}

\section{Supporting Facility}

Within the training program, the participants should equip themselves with the following tools and materials: water colour drawing paper, ground paper, black linen paper, coffee paper, scented red paper, buffalo paper with any colour and shape, duplex paper, pencil sharpener, aquarelle colouring pencil, colouring marker, water cup, brush, paper clip and hand wiper. 

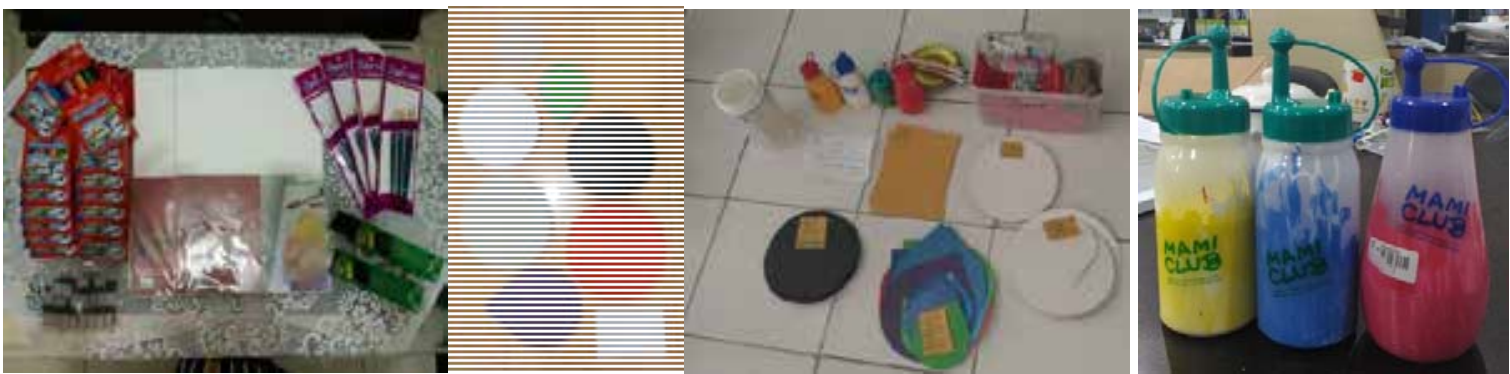

Figure 4. Tools and Materials

\section{Activity Stage}

The activities within the training program were performed through the following stages:

1. Re-registration and group division

The re-registration should be performed in order to attain the data of the attending participants. In this stage, the participants are seating in a circle in order to ease the distribution of the tools and the materials also the mentoring process by the instructor and the assistant.

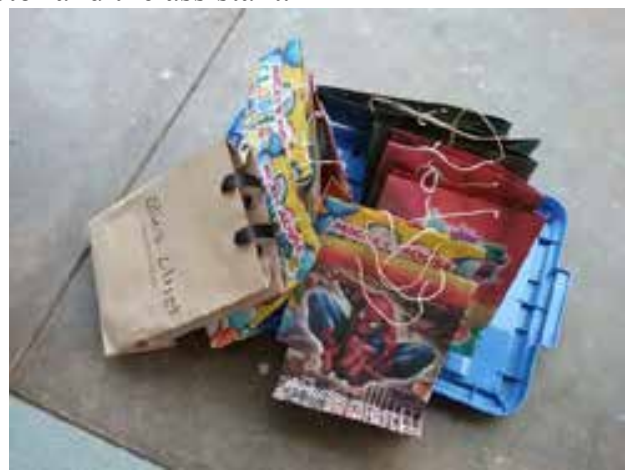

Figure 5. An example of the goodie bag containing the tools and the materials that should be distributed

2. Opening

The training program begun by hearing the foreword from the Chief of the Community Service Team, the caretakers from the UILS Meruya Selatan, and the caretakers of Bina Laras Harapan Sentosa 1 Social Homes Cengkareng. After listening to the forewords, the participant were invited to join the ice-breaking sessions and the introduction session with the Community Service Team.

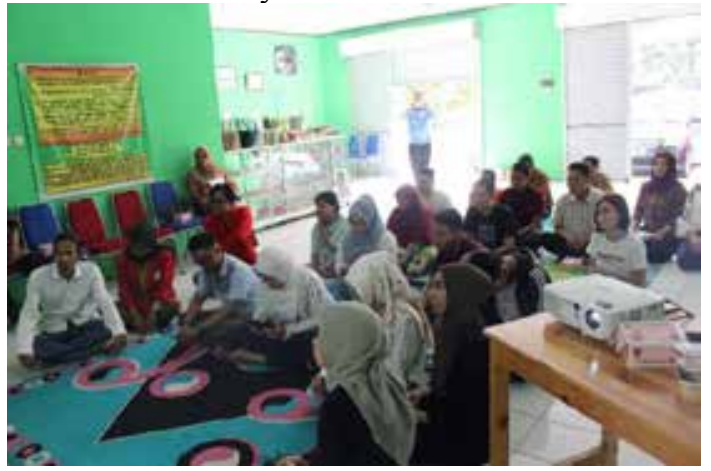

Figure 6. Opening session of the training program

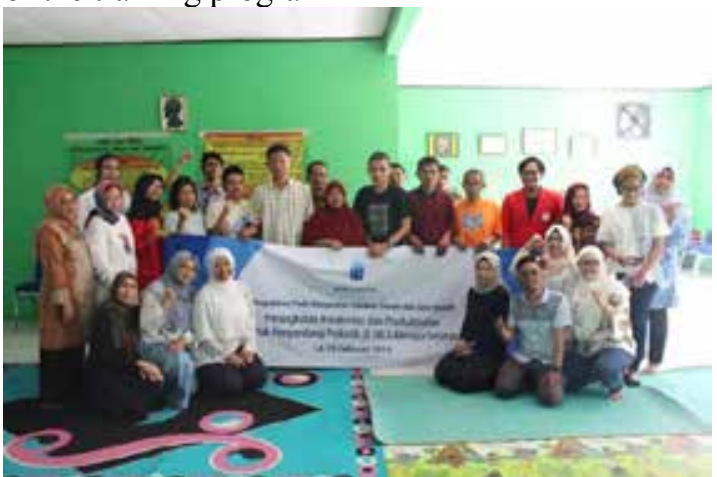

Figure 7. Photo session after the opening of the training program 
3. Theory Provision

The theory provision was intended to pursue the expected material understanding and output. In the same time, the participants were also motivated by providing the description on the development of art therapy and its function in recovering the mental disorders.

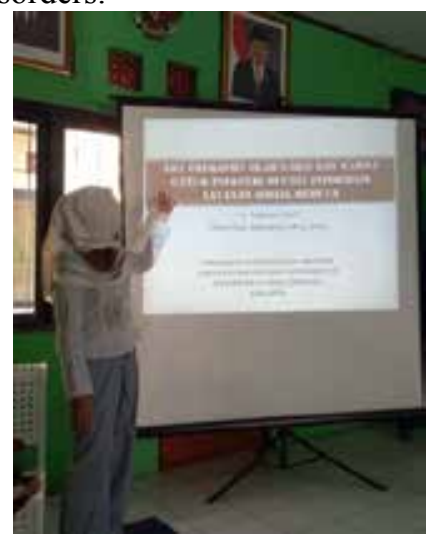

Figure 8. Provision of art therapy theory

4. Tools and Materials Introduction

In this stage, the participants were provided with the description about the tools and the materials that might be necessary for the art therapy.

5. Display and Role Model

In this stage, the instructor explained the stages in the therapy and demonstrated directly the drawing activities in front of the participants.

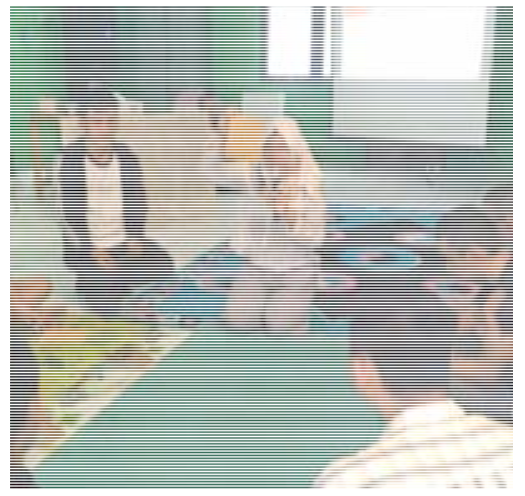

Figure 9. The instructor explained the stages of art therapy

6. Practice of Art Therapy

The practice of art therapy was performed by the participants under the direction by the instructor and the assistant. The participants were provided with the freedom to pour their ideas in the form of any style, line, colour and composition but they were still under the guidance of the instructor and the assistant.

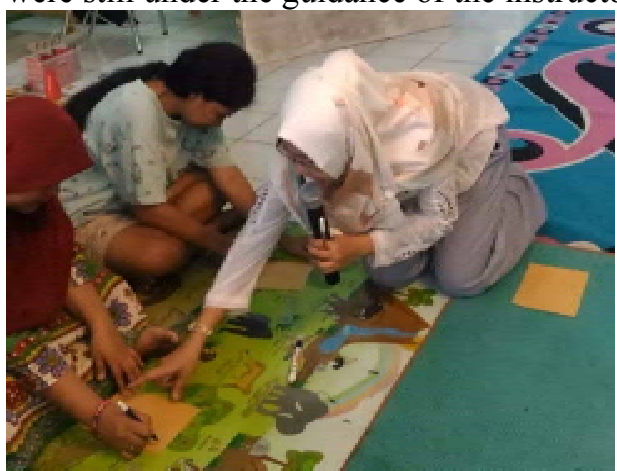

Figure 10. The instructor mentored the participants of Art Therapy

7. Sharing Moment

After the Art Therapy Training Program had been completed, the participants were directed to share about their artworks. 


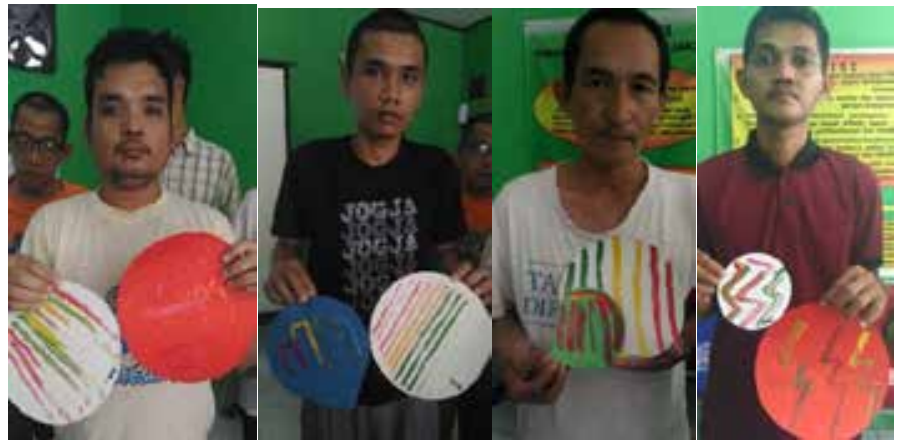

Figure 11. Participants and their artworks

\section{CONCLUSIONS}

From the conduct of Art Therapy Training Program in UILS Meruya, the researcher would like to draw the following conclusions:

1. The participants are able to attend the Art Therapy Training Program well.

2. Within the time allocation, the participants might attend the Art Therapy Training Program with good recovery process.

3. The techniques of Art Therapy heavily rely on the creatively spontaneous ideas and the skilful motoric hands.

\section{REFERENCES}

Anonymous. (2019). Psychoanalysis. Website: http://www.freudfile.org/psychoanalysis/definition.html. Last update: August $19^{\text {th }}, 2019$.

Arasteh, A.R. \& Arasteh, J.D. (1976). Creativity in Human Development. New York: John Wiley \& Sons.

Damajanti. (2013). Psikologi Seni: Bandung: Penerbit ITB.

Feldman, E.B. (1967). Art as Image and Idea. New Jersey: Prentice-Hall Inc.

Maftuka, Nina. 2018. Art Therapy: Seni Lukis Ekspresif untuk Penderita Gangguan Kejiawaan di Unit Informasi Layanan Sosial Meruya Selatan. Vol. 4 Edisi 3, Desember 2017.

Maftukha, Nina. (2018). Psikoanalisis pada Visualisasi Karya Penderita Gangguan Kejiwaan di Unit Informasi Layanan Sosial Meruya Selatan. Penelitian Internal University Mercu Buana Jakarta.

Tabrani. Bahasa Rupa. Bandung: Penerbit ITB. 